\title{
Правопреемство государств в некодифицированных областях
}

Кремнев П.П."

Как известно, в Венской конвенции О правоприемстве государств в отношении договров от 23 августа 1978 г. (далее «Конвенция 1978 г.») и Венской конвенции О правопреемстве государств в отношении государственной собственности, государственньг архивов и государственных долгов от 8 апреля 1983 г. (далее «Конвенция 1983 г.») кодифицированы нормы о правопреемстве государств в конкретных областях: в отношении договоров, государственной собсственности, государственных архивов и государственных долгов. А существуют ли иные области (сферы, предметы, материя синонимы данного понятия) того предмета («содержания правопреемства»'), в отношении которого наступают последствия правопреемства? В Конвенции 1983 г. на этот счет содержится лишь своего рода «защитительная оговорка» в весьма краткой ст. 5: ничто в настоящей Конвенции не должно рассматриваться как предрешающее в какомлибо отношении любой вопрос, касающийся последствий правопреемства в других областях, помимо тех, которые предусмотрены в Конвенции. Комиссия международного права практически не привела своего комментария к данной статье и только указала, что проект статей Конвенции не касается правопреемства в отношении всех других областей, он, скорее, ограничивается сферой применения в трех регулируемых областя ${ }^{2}$. Ответ на этот вопрос следует искать как в науке (по существу, в разрозненных и отрывочных замечаниях), так и в практике государств (также фрагментарной и неявной). Постановка данной проблемы с учетом ее мало изученного характера в отечествен-

Кремнев Петр Петрович - доцент кафедры международного права МГУ им. М.В. Ломоносова.

' Терминология КМП: Доклад Комиссии международного права о работеее тридцать первой сессии. Генеральная Ассамблея. Официальные отчеты. Тридцать четвертая сессия. Дополнение № 10 (А/34/10). Нью-Йорк, 1978. С. 14 (далее: Доклад Комиссии международного права о работе еетридцать первой сессии...).

${ }^{2}$ Доклад Комиссии международного права о работееетридцать первой сессии... С. 54-55. 
ной науке представляет несомненный доктринальный интерес.

Еще на своей XV сессии в 1963 г. всю проблему правопреемства Комиссия разделила на три основные темы: «правопреемство в отношении договоров; правопреемство в отношении прав и обязанностей, возникающих из иных источников, помимо договоров; nравопреемства в отночении членства в международных организациях (Выделено автором, К.П.)»³. На XVI сессии в 1964 г. Комиссия утвердила программу своей долгосрочной работы и назначила спецдокладчиков по первым двум темам, однако тогда же было решено «пока не касаться» и не назначать спецдокладчика по третьей теме, т.к. этот вопрос затрагивает как правопреемство в отношении договоров, так и отношения межлу государствами и международными организациями ${ }^{4}$. В дальнейшем вопрос о правопреемстве членства в международных организациях лишь «Глухо упоминался» во вводной части докладов КМП о работе ее XXVI и XXVII сессий5 и отдельного исследования в рамках работы Комиссии так и не получил. Д. О'Коннел в своей работе «Правопреемство государств» придавал особое значение данному вопросу и полагал, что «...в будущем это, по всей вероятности, будет одним из наиболее важных последствий перемены суверенитета» ${ }^{6}$. Указанный вопрос также вскользь затрагивается в некоторых учебниках по международному праву?

В Конвенции 1978 г. устанавливается, что она применяется к последствиям правопреемства государств в отношении «любого договора, являющегося учредительным актом международной организации, без ущерба для правил о приобретении членства... данной организации» (ст. 4). До настоящего времени не известно (во всяком случае, обнаружить таковые автору не удалось) ни одной международной организации, которая бы установила нормы о правопреемстве членства в ней.

Между тем правопреемство государств в отношении членства в международных организациях фактически существует, но при этом устойчивая и единообразная практика, а тем более нормы общего международного права отсутствуют. В рамках ООН, например,

\footnotetext{
3 Там же. С. 9.

${ }^{4}$ Там же. С. 11.

${ }^{5}$ Ушаков Н.А. Правопреемство государств. Уфа, 1996. С. 20.

${ }^{6}$ О'Коннелл Д. Правопреемство государств. М., 1957. С. 113.

${ }^{7}$ Международное право / Отв. ред. Г.И. Тункин.. М., 1994. С. 98; Международное право / Отв. ред. Ю.М. Колосов, В.Н. Кузнецов.. М., 1999. С. 70.
} 
Индия продолжила членство в Организации, а отделившийся от нее Пакистан проходил процедуру приема. Однако после выхода из состава ОАР Сирии она продолжила членство в ООН. После разделения федерации Мали на Сенегал и Республику Мали (бывший Французский Судан) они принимались в качестве новых членов Организации («хотя этот случай принципиально не отличался от случая Индия Пакистан $\rangle^{8}$ ), то же самое произошло после разделения ЧССР на Чехию и Словакию. После прекращения существования СССР одно из государств-преемников, Российская Федерация, продолжило его членство в системе органов ООН, а остальные бывшие союзные республики, кроме Беларуси и Украины, вступали в Организацию в качестве ее новых членов. Вместе с тем после выхода из состава СФРЮ четырех республик (они проходили процедуру приема в ООН) ее оставшаяся часть, в то время Федеративная Республика Югославия, с 1992 г. придерживалась позиции «автоматического продолжения членства в ООН», но по решению ГА ООН она была принята в качестве нового члена Организации только 1 ноября 2000 г. ${ }^{9}$. Практика в этой области специализированных учреждений ООН (МОТ, ИКАО, ВПС, МСЭ, ВОЗ) несколько иная ${ }^{10}$. Таким образом, решение по данному вопросу принимается каждой международной организацией в каждом отдельном случае. В связи с этим кодификация указанной сферы навряд ли целесообразна и вообще возможна.

В целом межгосударственная практика в вопросе о правопреемстве членства в международных организациях применительно к категории отделения части территории или разделения государства сводится к следуюшему: 1. Государство-предшественник (или одно из государств-преемников) продолжает членство, государство-преемник (или несколько государств-преемников) проходит процедуру приема; 2. Оба государства-преемника (или несколько государств-преемников) вступают в организацию в качестве ее новых членов; 3 . И государствопредшественник, и государство-преемник (или оба государства-преемники) продолжают членство без процедуры их принятия.

По мнению Н.А. Ушакова, иные (кроме уже кодифицированных)

\footnotetext{
${ }^{8}$ Аваков М.М. Правопреемство освободившихся государств. М., 1983. С. 37.

${ }_{9}$ Multilateral Treaties Deposited with the Secretary General. Status as at 31. December 2004.Vol.I. United Nations. New-York, 2005. P. XIII.

${ }^{10} \mathrm{Cм} .:$ О'Коннелл Д. Указ. соч. С. 116.
} 
области правопреемства государств отсутствуют, а упоминавшаяся ст. 5 Конвенции 1983 г. в качества saving clause служит «спасительной клаузулой, отсылающей в никуда. Клаузула на всякий случай» ${ }^{11}$. Представляется, что ценность данного утверждения больше заключается в красочности метафоры, чем в соответствии современным международно-правовым реалиям. В самом общем виде обоснование сводится к следующему. Каждому государству присущи три основных компонента: население, территория и власть. И поскольку государство-преемник наследует два материалыных компонента: население и территорию, то на них также распространяются и последствия правопреемств ${ }^{12}$. Если государство-преемник свободно в выборе основ и формы публичной власти (на основе государственного суверенитета), то согласно современному международному праву оно не может по своему усмотрению устанавливать статус населения (т.е. его гражданство) и границы наследуемой территории. Еще на своей ХХ сессии члены Комиссии межлународного права поднимали вопрос о правопреемстве государств в отношении «территориальных проблем, статуса жителей и приобретенных прав» ${ }^{13}$ и высказали в этой связи замечания предварительного характера. В то время Комиссия решила сосредоточить свои усилия на подготовке проектов статей, легших в основу Венских конвенций 1978 и 1983 гг., однако, как было при этом заявлено, «это отнодь не должно означать, что все остальные относящиеся к данной теме вопросы не будут рассмотрены позднее» ${ }^{14}$.

Что касается проблемы гражданства населения, затронутого правопреемством государств, то уже начиная с конца XIX века этот вопрос получил широкое рассмотрение в правовой доктрине ${ }^{15}$ и судеб̆ной практике. При рассмотрении таких дел о гражданстве националыные суды выносили многочисленные решения о недопусти-

${ }^{11}$ Ушаков Н.А. Указ. соч. С. 21.

"При всем глубоком уважении кпрофессору Н.А. Ушакову, истина дороже.

${ }^{12} \mathrm{C}$. Черниченко, выделяя внутренний и внешний аспекты правопреемства, указьвает: «В сфере внутреннего правопреемства наблюдается гораздо больший автоматизм, чем в сфере внешнего. В первую очередь это относится к территории и населению.» См.: Черниченко С.В. Теория международного права. Т. II. С.91 .

${ }^{13}$ Yearbook of the International Law Commission 1968. Vol. II. Р. 220 // Доклад Комиссии международного права о работе ее тридцать первой сессии... С. 15.

${ }^{14}$ Ibid. P. 221.

${ }^{15}$ См.: О'Коннелл Д. Указ. соч. С. 357; Международное публичное право: Учебник / Под ред. К.А. Бекяшева. М., 1998. С. 128-130. 
мости «обращения в гражданство насильственно», требуя предоставления права выбора гражданства. Также указывалось: «Нежелательно, чтобы в результате перемены суверенитета лица вопреки своей воле становились апатридами» ${ }^{16}$. Подобные или схожие положения содержались в Сен-Жерменском договоре (ст. 64) и Трианонском договоре (ст. 56) ${ }^{17}$ после распада Австро-Венгерской империи, в консультативных заключениях Постоянной Палаты Международного Правосудия по делам 1923 г. ${ }^{18}$, а также закрепляются в национальном законодательстве государств-преемников после разделения СФРЮ и ЧССР ${ }^{19}$. На основании этого можно предположить, что в данной сфере сложилась достаточно устойчивая практика: на смену принципа автоматического гражданства при трансферте территории («гражданство населения следует за территорией») пришел принцип оптации (право выбора населением отходящей территориигражданства государства-предшественника или государства-преемника); при этом не должно возникать ситуации безгражданства.

Кроме этого, проблемы статуса затронутого правопреемством государств населения опосредованно касаются положения ряда международных договоров и актов, устанавливающих право каждого человека на гражданство (ст. 15 Всеобщей декларации прав человека 1948 г., ст. 24 Международного пакта о гражданских и политических правах 1964 г.), о недопущении дискриминации в вопросах гражданства (ст. 9 Конвенщии о сокращении безгражданства 1961 г.), утраты и приобретения гражданства в случаях правопреемства государств (ст. 18 Европейской конвенции о гражданстве от 14 мая 1997 г.) ${ }^{20}$.

Еще в середине прошлого века видные западные представители науки

${ }^{16}$ О'Коннелл Д. Указ. соч. С. 368.

${ }^{17}$ Комиссия международного права. Доклад о работе еепятьдесят первой сессии (3 мая - 23 июля 1999 г.). Генеральная Ассамблея. Пятьдесят четвертая сессия. Дополнение № 10 (А/54/10). ООН. Нью-Йорк, 1999. С. 80 (Далее - Комиссия международного права. Доклад о работе ее пятьдесят первой сессии...).

${ }_{18}$ Дела о «Приобретении польского гражданства» и «Указы огражданстве, изданные в Тунисе и Марокко» // Комиссия международного права. Доклад о работе ее пятьдесят первой сессии... С. 27, 62 .

${ }^{19}$ Акт о гражданстве Словении от 05.06.1991 г. (ст.40), Закон о гражданстве Хорватии от 26.06.1991 г. (ст. 30), Закон о гражданстве Боснии и Герцеговины с поправками 1993 г. (ст. 29), Закон Чешской Республики о приобретении и угратегражданства от 29.12.1992 г. (ст. 1), Закон о гражданствеСловацкой Республики от 19.01.1993 г. (ст. 2)//Там же. С. 81 . ${ }^{20}$ Об этом см.: Комиссия международного права. Доклад о работе еепятьдесят первой сессии... С. 26,62 . 
международного права отмечали, что «последствия изменения суверенитета для гражданства жителей [территории, затрагиваемой правопреемством] представляго собой одну из наиболее сложньх проблем в области правовьх норм о правопреемстве государств», а также указывали: «Эта тема, возможно, в большей степени, чем любая другая в сфере правовых норм о правопреемстве государств, срочно требует кодификации или разработки международных норм» ${ }^{21}$.

Комиссия международного права к исследованию данной проблемы приступила в 1993 г. - на свосй 45-й сессии она включила в перечень рассматриваемьх вопросов тему «Правопреемство государств и его последствия для гражданства физических лиц и государственной принадлежности юридических лиц ${ }^{22}$. По просьбе Генеральной Ассамблеи ООН ${ }^{23}$ Комиссия сосредоточила свои исследования на первой части проблемы и после рассмотрения пяти докладов (специальный докладчик В. Микулка) в 1999 г. подготовила Проект статей о гражданстве физических лиц в связи с правопреемством государств ${ }^{24}$. В преамбуле Проекта кроме указания на озабоченность международного сообщества решением проблем гражданства в связи с недавними случаями правопреемства государств и его рассмотрения рядом межлународных органов ${ }^{*}$ в общем виде презюмируется, что хотя вопросы гражданства в основном регулируются внутренним правом, компетенция государств в данной сфере может осуществляться только в пределах, устанавливаемых международным правом, а «право государства использовать свои дискреционные полномочия... не является безграничным» ${ }^{25}$. В принятом Проекте содержится 27 статей,

${ }^{21}$ O'Connell D.P. The Law of State Succession. Cambridge, 1956. P. 245, 258. Последняя фраза указанного издания на русском языкепереведена некорректно. См.: О'Коннелл Д. Правопреемство государств. М., 1957. С. 368.

${ }_{22}^{2}$ Официальные отчеты Генеральной Ассамблеи, сорок восьмая сессия. Дополнение№ 10 (А/48/10, пункт 44).

${ }^{23}$ Резолюция ГА ООН № 51/160 от 16 декабря 1996 г. //Официальные отчеты Генеральной Ассамблеи, пятьдесят первая сессия. Дополнение № 49 (А/51/49).

${ }^{24}$ Комиссия международного права. Доклад о работе ее пятьдесят первой сессии...

* Принятие Советом Европы в 1997 г. Европейской конвенции о гражданстве и Европейской комиссией за демократию через право (Венецианская комиссия) в 1996 г. Декларации о последствиях правопреемства государств для гражданства физических лиц; рассмотрение проблемы безг ражданства в результате правопреемства государств УПравлением Верховного комиссара ООН по делам беженцев (A/50/1 2/Add.1).

${ }^{25}$ Комиссия международного права. Доклад о работе ее пятьдесят первой сессии... C. 26-27. 
где в ключевой ст. 1 излагается главный принцип, из которого вытекают остальные проекты статей - признание права на гражданство в конкретном контексте правопреемства государств: «Любое лицо, которое на дату правопреемства государств имело гражданство государства-предшественника, независимо от способа приобретения гражданства, имеет право на гражданство по крайней мере одного из затрагиваемых государств».

Проектом также предусматривается запрещение дискриминации и произвольного принятия решений по вопросам гражданства (ст. 15 и 16), предоставления права оптации государствами-преемниками (ст. 23). В разделе 3, озаглавленном «Распад государств», устанавливается: «Когда какое-либо государство распадается и прекращает свое существование, а различные части государства-предшественника образуют два или несколько государств-преемников, каждое государство-преемник предоставляет свое гражданство, если только осуществление права оптации не означает иного» (ст. 22). Такой принцип, как это следует из анализа законодательства о гражданстве государств СНГ и прибалтийских республик ${ }^{26}$, был реализован со стороны всех бывших союзных республик, кроме Латвии и Эстонии ${ }^{27}$.

Подводя краткий итог рассматриваемому аспекту, можно констатировать, что в вопросах гражданства физических лиц в связи с правопреемством государств сложилась устойчивая межгосударственная практика, выработаны международно-правовые нормы обычного характера и отдельные конвенционные положения. Данная сфера представляет собой один из предметов правопреемства государств и находится в настоящее время в процессе кодификации и развития. Другой аспект проблемы - гражданство юридических лиц в связи с правопреемством государств - в науке международного права в настоящее время является практически не исследованным.

Правопреемство государств в отноиении территории. Как отмечалось ранее, вопрос о правопреемстве государств в отношении территории затрагивался (без анализа проблемы) в Комиссии

${ }^{26}$ См.: Смирнова Е.С. Международно-правовые проблемы гражданства стран СНГ и Балтии в свете европейского опыта. М., 1999.

${ }^{27}$ Об этом см.: Аксенов А.Б. О гражданстве в связи с правопреемством государств. Автореф. дис. ... канд. юрид. наук. Казань, 2005. С.19. 
международного права, отечественными и зарубежными авторами ${ }^{28}$. По мнению Н.А. Ушакова, «между государствами предшественником и преемником существует реальная связь - территориальная... Именно в этом глубокий смысл всей проблемы правопреемства в соответствии с международным правом» ${ }^{29}$. Ю.Г. Барсегов территориальные проблемы относит к «острому и важному вопросу, связанному с правопреемством ${ }^{30}$, а Г.Г. Шинкарецкая подвергает правовому анализу «акты правопреемства Российской Федерации в отношении границ $\rangle^{31}$.

Не требуется доказательств в том, что любое земное пространство, в том числе территория государства, определяется его границами. И любая наследуемая государством-преемником территория в случае отделения части территории или разделения государства также имеет свои границы. Теоретически нельзя исключать, что вся отделяющаяся от государства-предшественника территория может быть уже закреплена международными договорами о границе - островная территория или анклав, например; но едва ли не единственным практическим таким примером является отделение Сингапура. Поэтому по общему правилу территория государства-преемника частично закреплена (в большинстве случаев) международными договорами о границе и частично установлена внутренним правом государства-предшественника - это т.н. «административные границы» между государством-предшественником и государством-преемником или между государствами-преемниками. В первом случае (правопреемство территории, закрепленной международными договорами государства-предшественника с сопредельными странами) никаких проблем возникать не должно: фактически государство-преемник наследует межлународные договоры о границах. В отношении таких договоров действует общепризнанный принщип международного права о неприменимости положения о коренном изменении обстоятельств (клаузула rebus sic stantibus) в качестве основания для одностороннего прекрашения

\footnotetext{
${ }^{28}$ См., например: Аваков М.М. Указ. соч. С. 23; Шинкарецкая Г.Г. Проблемы правопреемства и границы Российской Федерации // Московский журнал международного права. 1995. № 4. С. 86-91; Хайд Ч. Международное право, его понимание и применение Соединенными Штатами Америки. Т. 2. М., 1952. С. 236-237.

${ }^{29}$ Ушаков Н.А. Указ. соч. С. 18-19.

${ }^{30}$ Барсегов Ю.Г. Вступительная статья к изданию: О’Коннелл Д. Правопреемство Государств. М., 1957. С. 7.

${ }^{31}$ Шинкарецкая Г.Г. Указ. соч. С.86.
} 
действия договора или выхода из него (п. 2 «а» ст. 62 Венской конвенции о праве международных договоров 1969 г. $)^{32}$. В дополнение к этому в Венской конвенции 1978 г. закреплено положение о том, что правопреемство государств как таковое не затрагивает границ, установленных договором (ст. 11). Но положения ст. 11 Конвенции 1978 г. запрещает не правопреемство территории как таковое: в данном случае преследуются идея правопреемства территории на основании принципа ipso jure (т.е. в границах существующих международных договоров), a не tabula rasa (т.е. пересмотра или отмены договоров о границах $)^{33}$. К тому же в некоторых ситуациях государство-преемник может наследовать территорию государства-предшественника, которая на момент правопреемства не была определена в договорном порядке с третьим сопредельным государством. Так, в свое время между СССР и Китаем существовали территориальные споры, в связи с чем имелись достаточно протяженные участки двустороннего размежевания территории, не урегулированные договорами. Государства - преемники таких территорий (Россия, Казахстан, Кыргызстан) заключали двусторонние договоры о границах с КНР уже впоследствии, причем на некоторых участках закрепляемая договорами граница не совпадала с линией размежевания, существовавшей на момент правопреемства (она была установлена в пользу Китая).

Сложная ситуация может возникнуть во втором случае - при правопреемстве территории, определяемой внутренними (административными) границами государства-предшественника, т.е. границами между государством-предшественником и государством-преемником или между государствами-преемниками. Поскольку такие административные границы во многих случаях устанавливались произвольно либоо в нарушение внутреннего законодательства государства-предшественника, то при наступлении события правопреемства государств это потенциально таило опасность возникновения территориальных споров или даже вооруженных конфликтов. О том, что это не только теоретические предположения, видно на примере распада югославской феде-

32 Подробнее см.: Талалаев А.Н. Венская конвенция о праве международных договоров. Комментарий. М., 1997. С. 173-174.

${ }^{33}$ См.: Шинкарецкая Г.Г. Проблемы правопреемства и границы Российской Федерации // Московский журнал международного права. 1995. № 4. С. 91 ; Доклад Комиссии международного права о работе ее XXVI сессии, 6 мая - 26 июля 1974 г. //Ежегодник Комиссии международного права. 1974. Том II, часть первая. Нью-Йорк, 1975. С. 251 . 
рации или отсоединения Эритреи от Эфиопии ${ }^{34}$. На момент правопреемства СССР территории бывших союзных республик определялись тремя видами границ: а) границы, закрепленные в договорах СССР о границах с сопредельными государствами; б) морские границы (территориальне море, а также ширина континенталыного шельфа и режимы прилежащей зоны и исключительной экономической зоны, устанавливаемые Законом «О государсгвенной границе СССР» 1982 г., при этом разграничение морских пространств между бывшими союзными республиками на Балтийском, Черном и Каспийском морях отсутствовало; в) административные границы между бывшими союзными республиками. Последние как раз и представляли собой наиболее сложную, запутанную и порой болезненную проблему в отношениях между ставшими независимыми государствами. Причиной этому послужила практика изменений территорий бывших союзных республик в нарушение союзно-республиканского законодательства ${ }^{35}$. При территориальном размежевании болышинство государств СНГ исходило из необходимости договорного закрепления фактически существующих границ, в то время как другие государства требовали приведения административных границ в соответствие с действовавшим тогда конституционным законодательством ${ }^{36}$. Несмотря на подписание в рамках СНГ нескольких многосторонних соглашений о неприкосновенности существующих между ними границ ${ }^{37}$, эта проблема оставалась и будет оставаться неурегулированной или даже спорной вплоть до заключения двусторонних договоров о границах между каждыми

\footnotetext{
${ }^{34}$ Некоторые африканские исследователи также отмечают, что «указанный принцип [uti possidetis] не распространяется на внутренние административные границы». Вооруженный конфликт между этими двумя государствами по поводу определения таких границ возник еще в мае 1998 г. и, несмотря на многочисленные рекомендации Совета Безопасности и посреднические усилия со стороны Генерального секретаря ООН, не разрешен до настояшего времени. См.: Ишету Сефанит Кетема. Роль международноправовых средств в разрешении эфиопско-эритрейского конфликта. Автореф. дис. ... канд. юрид. наук. М., 2004. С. 6, 18-19.

${ }^{35}$ Об этом подробно см.: Кремнев П.П. Распад СССР: международно-правовые проблемы. М., 2005. С. 43-91.

${ }^{36}$ См. также: Клименко Б.М. Проблемыправопреемствана территории бывшего СССР // Московский журнал международного права. 1992. № 1. С. 14-15.

37 Декларация о неприкосновенности границ от 7 августа 1993 г., Декларация о соблюдении суверенитета, территориальнй целостности и неприкосновенности границгосударств - участников Содружества Независимых Государств от 15 апреля 1993 г. // Действующее международное право. Т. 1. М., 1996. С. 195-198.
} 
сопредельными государствами. Как показало дальнейшее развитие событий, в данной сфере большинство государств, ранее входивших в состав бывшего СССР, на основе известного в международном праве принципа uti possidetis («чем владеете»*) осуществили последовательно два других принципа: от uti possidetis de facto (обладание фактическое) перешли к uti possidetis juris (обладание юридическое). Практически это означало первоначальное официальное признание фактических границ между ними, а затем их закрепление в двусторонних договорах; устанавливаемая линия границы отклонялась от фактической лишь в тех редких случаях, когда стороны обменивались небольшими участками территории (например, Россия и Казахстан, Казахстан и Узбекистан) $)^{38}$.

В итоге при наступлении события правопреемства государств правопреемство в отношении территории фактически существует. Однако кодификация данной сферы представляется нецелесообразной по следуюшим основаниям:

1. В общем международном праве уже существует общепризнанная норма о том, что правопреемство государств не затрагивает установленных международным договором границ между третьим государством и государством, затронутым событием правопреемства.

2. Границы между государством-предшественником и государствомпреемником (при отделении части территории государства) или между государствами-преемниками (при распаде государства) подлежат установлению только затрагиваемыми правопреемством государствами. Поэтому даже в случае кодификации такие нормы могут носить только общий и неизбежно отсылочный характер.

Вопрос о правопреемстве государств в отноиении междуна-

\footnotetext{
* Смысл данного принципа не столь однозначен, как может показаться. Согласно толкованию одного из самых известных в начале ХХ века специалистов римского права профессора Мура, этот термин означал исходящее от претора распоряжение, которым воспрещалось нарушение существующего положения вещей между двумя лицами в вопросе о владении недвижимым имуществом. Имелось в виду попросту запретить нарушение status quo, причем вопрос о том, какая из сторон является владельцем недвижимости, оставался открытым. Распоряжение претора звучало: "Uti possidetis, ita possidetis” («Чем владеете, тем владейте») // Хайд Ч. Указ. соч. С. 236.

${ }^{38}$ Интервью министра иностранных дел Казахстана Е. Идрисова: «Казахстан - Узбекистан»: пограничные проблемы будут решены цивилизованно» // Казахстанская правда. 20 апреля 2000 г.; Идрисов Е. Делимитация государственной границы: общественный контроль должен осуществляться объективно //Казахстанская правда. 29 октября 2001 г.
} 
родно-правовых норм обычного характера. В общей части Конвенции 1978 г. содержится ст. 5 под наименованием «Обязательства, имеющие силу на основании международного права независимо от договора», согласно которой «тот факт, что договор не считается находящимся в силе в отношении какого-либо государства в силу применения настоящей Конвенции, ни в коей мере не затрагивает обязанности этого государства выполнять любое записанное в договоре обязательство, которое имеет силу для него в соответствии с международным правом независимо от договора». Следовательно, речь идет об обязательствах, проистекающих из обычньх норм международного права. Данная статья почти дословно воспроизводит постановляющую часть ст. 43 Венской конвенции о праве межлународньх договоров 1969 г.: «Недействительность, прекращение или денонсация договора ... ни в косй мере не затрагивает обязанности государства ... которое имеет силу для него в соответствии с международным правом, независимо от договора». В весьма (и неоправданно) кратком комментарии Комиссии международного права к проекту ст. 5 Конвенции 1978 г. указывается: «По этой причине Комиссия сочла желательным включить общее положение в части I проекта, уточняющее, что прекращение действия договора при правопреемстве государств в результате применения проекта никоим образом не освобождает государство-преемника от предусмотренных договором обязательств, которые являются также обязательствами, распространяющимися на него в соответствии с международным правом независимо от договора» ${ }^{39}$. В проекте ст. 5 «Комиссия опустила слово «преемник» из выражения «государство-преемник»...потому что... договор может считаться находящимся в силе не только в отношении государства-преемника, но также в отношении других государств $)^{40}$. Характерно, что при разработке проекта ст. 43 Конвенции 1969 г. Комиссия отмечала, что «этот вопрос можно считать в качестве аксиомы» ${ }^{41}$. С данной «аксиомой» вполне можно согласиться на том основании, что применительно к Конвенции 1969 г. речь идет о договорном закреплении уже существующих каких-либо определенных норм обычного происхож-

${ }^{39}$ Ежегодник Комиссии международного права. 1974. Том II. Часть первая. ООН. НьюЙорк, 1975. С. 218.

40 Tам же.

${ }^{41}$ Official Records of the United Nations Conference on the Law of Treaties. Documents of the Conference. P. 57. 
дения, в отношении обязательности которых какое-либо определенное государство уже ранее выразило свое согласие. Но ст. 5 Конвенции 1978 г. регулирует иную правовую ситуацию, и в этом, как отмечается в отечественной доктрине, состоит ее некорректность ${ }^{42}$.

Несовершенство определения правовой нормы создает трудности ее понимания и эффективного применения. Для целей практического применения ст. 5 в том виде, как она принята, следует исходить из систематического толкования, которое подразумевает анализ нормы договора на основе ее исследования с другими постановлениями договора и иньх действующих норм международного права. Иначе говоря, ст. 5 Конвенции 1978 г. должна толковаться в системе целей, принципов и норм, находящихся во взаимной связи. Исходя из смысла ст. 5 и комментариев к ней Комиссии, она затрагивает 3 категории государств: третье государство (не затронутое событием правопреемства, но являাщееся одним из участников двустороннего или многостороннего договора с государством-предшественником), государство-предшественник и государство-преемник. В отношении первых двух категорий вопросов не возникает, т.к. их положение не отличается принципиально от случаев, регулируемых Конвенцией 1969 г. (ст. 43), и международные обычаи продолжают для них оставаться в силе. Государство-преемник находится в иной ситуации. Во-первых, в случае нового независимого государства возникает противоречие с другими положениями Конвенции 1978 г.: почему в отношении норм договоров государства-предшественника новое независимое государство может действовать на основании принципа tabula rasa (ст. 17 и 18), а в отношении норм обычного характера (обязательных для государства-предшественника) для него должен действовать принцип ipso jure (т.е. сохранения их обязательной силы)? Во-вторых, распространение силы международных обычаев диспозитивного характера на любое новое государство с момента его возникновения в отношениях с другими государствами фактически равносильно утверждению, что часть государств (пусть и болытая или из ведущих государств мира) путем формирования обычая может навязывать остальным государствам нормы общеобязательного характера, т.е. осуществлять функции «международного законодателя). Это противоречит самой согласительной природе современного международного права; такой тезис поднимал-

${ }^{42}$ Ушаков Н.А. Указ. соч. С. 33. 
ся в доктрине, но не получил всеобщего признания в науке и не был воспринят международным сообществом государств ${ }^{43}$.

Проблема правопреемства международных обычаев в современной теории международного права является недостаточно исследованной, и единства мнений в ней не наблюдается. В прошлом в западной доктрине в целом преобладала точка зрения, согласно которой «действие всеобщего международного обычного права не затрагивается правопреемством государств. Вновь возникаюшее государство автоматически связано всеобще действующим обычным международным правом» ${ }^{44}$. В противовес «буржуазным международникам» болышинство советских юристов выражали полное несогласие с такой позицией и указывали, что международное обычное право входит в «правовую материю» правопреемства, в отношении которого новое независимое государство вправе выразить свое отношение и находится в таком же положении, как и в случае преемства договоров ${ }^{45}$. В то время данная проблема рассматривалась в контексте дискуссии о юридической силе обычных норм общего международного права, которые были признаны таковыми значителыным числом государств, но «никогда не были приняты новыми государствами [например, социалистическими или вновь образовавшимися государствами Азии и Африки] и могут оказаться частично или полностью неприемлемыми для них $)^{46}$. В целом в отечественной доктрине признавалось, что «исходя из принципов суверенитета и равноправия государств новое государство определяет свое отношение к существующим нормам общего международного права так же свободно, как все другие государства определяли свое отношение ко вновь возникаюшим нормам международного права $)^{47}$. В международном праве на смену классовому подходу пришел принцип общечеловеческих ценностей, все бывшие колониальные государства уже достигли независимости, но проблема правопреемства международных обычаев осталась. В самом деле, распространяется ли после события правопреемства государств ори-

${ }^{43}$ См.: Ушаков Н.А. Указ. соч. С. 33.

44 Захарова Н.В. Правопреемство государств. М., 1973. С. 68; подробнее по данному вопросу см.: Коробова М.А. Расширение оферы действия норм общего многостороннего договора. М., 1983. С. 92-94, 99-104.

45 Захарова Н.В. Указ. соч. С. 68-69.

${ }^{46}$ Тункин Г.И. Теория международного права. М., 1970С. 150.

${ }^{47}$ Коробова М.А. Указ. соч. С. 103. 
дическая сила международного обычая на государство-преемник? Ни предыдуцая практика, ни последние случаи правопреемства государств не дают на это какого-либо вразумительного ответа: в сделанных официальных заявлениях государсгв-преемников (республик бывшей югославской федерации, Чехии и Словакии) указывается о правопреемстве только договорных обязательств государства-предшественника. Не разьясняет ситуацию и событие правопреемства бывшего Союза ССР: в Соглашении о создании СНГ (ст. 12) и известной ноте МИД РФ от 13 января 1992 г. говорится о выполнении не всех международно-правовых обязательств, а лишь «обязательств, вытекающих из договоров, заключенных Союзом ССР». На последней конференции Ассоциации межлународного права в Берлине в 2004 г. (секция «Aspects of the law of state succession») в ходе дискуссий также отмечалось, что по данному вопросу не существует никакой ясности.

Представляется, что подходк данной проблеме должен основываться на теории современного международного права. Международные обычаи являются одним из источников или видов норм международного права, так же как и международные договоры. И поскольку последние являются одним из предметов (областей, «правовой материей») правопреемства государств, то таким же предметом, вероятно, могут быть и международные обычаи. Должно быть очевидно, что событие правопреемства государств не затрагивает императивных норм общего международного права, которые независимо от своей формы (конвенционные или обычные) обязательны для всех государств мирового сообщества. Также представляется, что правопреемство государств как таковое не затрагивает и иные (не имеющие императивного характера) общепризнанные принципы и нормы общего международного права: например, дипломатической неприкосновенности, свободы открьтого моря и воздушных полетов над ним, необходимость делать различие между воюющими и гражданскими лицами во время вооруженных конфликтов и т.д. В отношении таких норм в доктрине также употребляго термин «автоматическое правопреемство» ${ }^{48}$. Подтверждением данной презумпции является, в частности, решение Международного Суда ООН от 11 июля 1996 г. по делу «Босния и Герцеговина против Югославии». Суд установил, что независимо от вопроса, является ли Босния и Герцеговина участником Конвенции о предуп-

48 Черниченко С.В. Указ. соч. С. 95. 
реждении преступления геноцида и наказании за него от 9 декабря 1948 г. на основании принципа «автоматического правопреемства» или нет, положения Конвенции представляют собой права и обязательства erga omnes и не имеют территориального ограничения ${ }^{49}$. Таким образом, императивные нормы и общепризнанные принципы общего международного права, в том числе обычного происхождения, не могут являться предметом правопреемства государств, они обязательны для выполнения всеми государствами, включая и государства-преемники.

Межлународные обычаи иного характера являготся диспозитивными. По этой причине они могут входить в «правовую материю» правопреемства, и государство-преемник должно иметь право определить к ним свое отношение - признавать или не признавать в отношении себя их юридическую силу. Подход к этому в своей основе может учитывать практику правопреемства государств в отношении международных договоров. По всей вероятности, к государству-преемнику могут иметь отношение те обычаи, в формировании которых участвовало государство-предшественник либо имело практику их применения. Неуместно, как кажется, ставить вопрос о преемстве портовых обычаев государством-преемником, не имеющим выхода к открытому морю и практики судовождения со стороны его государства-предшественника. В целом же в современном международном праве в отношении правопреемства международных обычаев диспозитивного характера отсутствуют не только нормы, но и сколько-нибудь устойчивая практика, которой могли бы руководствоваться государствапреемники. Применительно к такой ситуации уместно привести формулировку, к которой прибегла Постоянная Палата Международного Правосудия в решении по одному из подобных дел: Палата «скептически отнеслась к возможности существования какой бы то ни было общей нормы, ссылаясь не «изменчивость международной практика и хаотический разнобой в теоретических высказываниях авторитетов $)^{50}$.

На основании изложенного представляется обоснованной постановка вопроса о том, что при наступлении события правопреемства государств предметами правопресмства также являются: членство в меж-

\footnotetext{
${ }^{49}$ Application of the Convention on the Prevention and Punishment of the Crime of Genocide (Bosnia and Herzegovinav. Yugoslavia). Order of 11 July 1996. ICJ Rep. (1996). Para. 23, 31. ${ }^{50}$ Броунли Я. Международное право. Кн. 2. М., 1977. С. 391.
} 
дународных организациях (применительно к государству-преемнику), гражданство (населения и юридических лиц) и территория затрагиваемых правопреемством государств. В указанных областях поведение государства-преемника может быть основано не на принципе tabula rasa, a с учетом сложившейся практики межгосударственных отношений и исходя из имеющихся международно-правовых норм. Событие правопреемства государств не затрагивает международные обычаи, содержащие императивные нормы и другие общепризнанные обязательства erga omnes (или иначе их «автоматическое правопреемство»); правопреемство в отношении иных норм международных обычаев осуществляется в соответствии с практикой преемства норм межлународного договора. 